\title{
Competitive ability of grain-forage varieties of spring vetch when grown in a mixture with rapeseed
}

\author{
A.V. Bezgodov ${ }^{1, *}$, K.A. Galimov ${ }^{1}$, and V.F. Akhmetkhanov ${ }^{1}$ \\ ${ }^{1}$ Federal State Budgetary Institution "Ural Federal Agrarian Scientific Research Center of the Ural \\ Branch of the Russian Academy of Sciences", 620142 Yekaterinburg, Russia
}

\begin{abstract}
The object of the research is to study the influence of the method of growing mown and grain-forage varieties of spring vetch in mixed crops with spring rapeseed on the seed yield and crop structure. Indicators that characterize productivity, intensity of arable land use, competitiveness and aggressiveness of crops are considered. Sowing spring vetch with a seeding rate of 1.3, 0.8, 0.6 and 0.4 million germinating seeds per hectare mixed with rapeseed leads to the formation of a grain crop that significantly exceeds the yield for single-species vetch sowing. Evaluation of Land Equivalent Ratio (LER) shows that when using vetch-rapeseed crops, the productivity of 1 ha of arable land increases from 1.38 to 1.98 times, while both the influence of varietal specificity and the seeding rate of the legume component is manifested. The efficiency of arable land use increases due to the interaction of both crops and increasing their competitiveness in the agrocenosis. In the conditions of the Middle Urals, high efficiency of vetch cultivation in mixed crops with rapeseed was revealed, and the influence of changes in the seeding rate on the yield of spring vetch seeds was established.
\end{abstract}

\section{Introduction}

The growth of livestock production is directly related to the provision of high-protein feed. It is advisable to use any source of protein that can cover its lack in the diets of farm animals. One of these sources of protein is vetch. However, it does not occupy the areas corresponding to its value in agricultural production. The reason for this is objective and subjective circumstances (1).

Spring vetch is a non-perennial legume crop grown to produce green mass, hay, haylage and grain, which is almost as valuable as clover and alfalfa in terms of feed value. Vetch seeds contain on average from 27 to $35 \%$ protein, while straw contains $6-10 \%$, hay contains $18-22 \%$, and green mass contains $3.5 \%$. Vetch protein has a high digestibility coefficient and is well balanced with essential amino acids, including lysine and tryptophan. The high feed productivity of the crop is evidenced by the high availability of $1 \mathrm{c}$. u. of raw (187-223 g) and digestible (164-196 g) protein (2-4).

Scientific studies have shown that the grain of new grain-forage varieties of vetch is practically harmless when it is directly used as a protein component in mixed feeds. It was

* Corresponding author: spagro@list.ru 
found that in terms of total nutrition and raw protein content, vetch surpasses peas and fodder beans, but is inferior to blue lupine and soy. Based on the generalized experimental data, the following norms for the introduction of vetch grain into feed can be recommended: cows-15 $\%$, young cattle - $20 \%, 2-4$ months young pigs - $10 \%$, fattening pigs - $15 \%$, sows - $20 \%$, broiler chickens - $15 \%$, adult poultry - $20 \%$ (1).

Favorable conditions are created for the growth and development of mixed crops of spring vetch with cereal components. In cereal components (oat and barley), nitrogen nutrition is improved, and an active increase in vegetative mass is observed $(5,6)$. To obtain feed balanced in protein, carotene and other nutrients, it is recommended to increase the area for mixed crops of grain-forage and legumes. This can contribute to an increase in yield by $25-$ $45 \%$ compared to pure crops of forage crops (7).

Unstable years by seed production, depending on weather conditions and crop yield, nonprovision of the needs of the agricultural seed material, high loss of grain during harvesting of single-variety vetch crops, low breeding coefficient, and higher costs in the production of seed in mixtures with cereals - the major causes of decline in spring vetch acreage in Russia. All these factors point to the need to develop fundamentally new technologies for the cultivation of this crop for seed and forage purposes, which are radically different from the technologies for the cultivation of mixed crops for the production of rough and succulent feed.

Numerous studies have confirmed that in mixed crops of legumes with barley and oat, the cereal component dominates the legume and the yield of the legume component in comparison with single-species crops is significantly reduced.

The need for research on mixed vetch-rapeseed crops is determined by the biology of crops. Spring vetch is a light-loving plant with a long development day. With a lack of light, there is an increased growth of stems, elongation of the root system, decrease in flowering and fruiting productivity, decrease in the content of the most valuable components in the grain - proteins, sugars, starch. At the young age the plant more tolerant to shading than in the later phase of ontogeny. The most light-sensitive period is the formation and maturation of beans and seeds. Spring rapeseed has a strong and branched stem, by the time the seeds ripen in the pods, its leaf apparatus completely dies off. This helps to increase the use of solar energy by the second component.

N.P. Lukashevich, I.M. Koval, and others established that the methods of cultivation of leguminous crops have a significant impact on both the overall yield of grain fodder and the legume component. In mixed crops where spring rapeseed was used, the seed yield of the support plant was low, at the level of 5.8-6.8 c/ha. The share of legumes was at the level of 21.7-23.0 c/ha. Varietal specificity in this case was not identified (8).

Génard T. et al. established a reliable nitrogen transfer from lupine and clover to rapeseed, while vetch's nitrogen transfer was unreliable (9). Studies by Couëdel A. et al. have shown that many cruciferous crops can be combined with different legumes to create agroecosystems with different useful characteristics (10).

Studies conducted in the conditions of the Middle Urals on mown varieties of vetch showed that to increase the seed yield, it is promising to grow it in mixed crops with spring rapeseed. Such crops of vetch with rapeseed can reduce the rate of seeding of vetch seeds by $55-70 \%$, reducing the lodging of vetch, and increase the yield of grain mixtures from 37.5 to $68.1 \%(11)$.

\section{Research methodology and methods}

The studies were performed in the FSBSI UrFASRC UrD RAD within the framework of the State task of the FASO of Russia in the direction 151 and the FSR program of the state academies of sciences on the theme "Theory and principles of development and formation of 
technologies of cultivation of economically important agricultural crops for the purposes of designing of a highly productive agro-phytocenosis and agro-ecosystems".

Field experiments were conducted on dark gray forest heavy loamy soil with the content of: humus $3.91 \%$, N easily hydrolyzed $-96 \mathrm{mg} / \mathrm{kg}, \mathrm{P}_{2} \mathrm{O}_{5}-205 \mathrm{mg} / \mathrm{kg}, \mathrm{K}_{2} \mathrm{O}-82 \mathrm{mg} / \mathrm{kg}$ of soil, $\mathrm{pH}-5.5, \mathrm{~N}_{\mathrm{h}}-5.85 \mathrm{mmol} / 100 \mathrm{~g}$ of soil, $\mathrm{S}$ of absorbed bases $-27.4 \mathrm{mmol} / 100 \mathrm{~g}$ of soil. The registered plot area is $13.5 \mathrm{~m}^{2}$, the repetition is three times. Complex fertilizer azophoska at a dose of $\mathrm{N}_{30} \mathrm{P}_{30} \mathrm{~K}_{30}$ was applied for pre-sowing cultivation.

Studies were carried out on two grain varieties (Lugovskaya 98, Lyuba). The 100\% seeding rate is 1.3 million germinating seeds per ha of vetch. Spring rapeseed (Luch variety) was sown with a rate of 1.25 million germinating seeds per ha. Seeding was carried out on May 13-15. Immediately after the crops were rolled, they were treated with the herbicide at a dose $200 \mathrm{ml} / \mathrm{ha}$ (rate of application clomazone). To control pests, vetch and rapeseed seeds were treated with an insecticidal protectant before sowing, and vegetating plants were treated with insecticide once during the budding phase - the beginning of rapeseed flowering.

\section{Results}

Weather conditions in 2017 and 2018 were significantly different. 2017 was characterized by arid conditions against the background of high temperatures throughout the growing season, while in 2018 the growing season was characterized by a lack of temperatures with excessive moisture. Nevertheless, regardless of weather conditions, single-species crops of all the studied varieties of vetch were completely flattened by the time of lodging, which made it much more difficult to thresh them. For the Lyuba variety, there was a slightly less pronounced lodging of plants, but some of the plants also completely lay on the ground.

In polymorphic crops for all varieties of vetch, there was a decrease in the degree of plant lodging with a decrease in the seeding rate and, accordingly, the share of the legume component in the mixture. At the same time, the degree of lodging also depended on the level of the formed crop of legumes. It should be noted that vetch lodging in polymorphic crops is radically different from lodging in mono-seeding. The presence of rapeseed plants in a two-component mixture with vetch during their lodging does not allow vetch plants to lie down on the soil. Due to the plasticity of the rapeseed stems, an air cushion of 20 to $30 \mathrm{~cm}$ high remains between the soil and plants, which does not lead to vetch beans rotting and does not complicate the combine harvesting.

Evaluation of grain-forage varieties of spring vetch when cultivated in the Middle Urals has not been previously carried out. Studies have shown a significant difference in grain yield in the varieties Lyuba and Lugovskaya 98 when they are cultivated in this region. Despite the increase in the yield of binary crops, the yield of vetch grain in the Lyuba variety at full seeding rate was at the level of single-species seeding, and with a decrease in the seeding rate, it significantly decreased with a simultaneous increase in the yield of rapeseed (table 1).

Table 1. Grain yield of spring vetch in the polymorphic crops, 2017-2018.

\begin{tabular}{|c|c|c|c|c|c|c|c|}
\hline \multirow[t]{2}{*}{ Variant } & \multirow{2}{*}{$\begin{array}{l}\text { Resistance } \\
\text { to lodging, } \\
\text { point }\end{array}$} & \multicolumn{6}{|c|}{ Yield, t/ha } \\
\hline & & total & $S_{\bar{x}}$ & vetch & $S_{\bar{x}}$ & rapeseed & $S_{\bar{x}}$ \\
\hline \multicolumn{8}{|c|}{ Lyuba variety } \\
\hline $\begin{array}{l}1.3 \text { million } \\
\text { (contr.) }\end{array}$ & 1 & 1.16 & 0.25 & 1.16 & 0.16 & - & - \\
\hline $\begin{array}{l}1.3 \text { million } \\
+ \text { rapeseed }\end{array}$ & 2 & 2.15 & 0.11 & 1.17 & 0.11 & 0.97 & 0.01 \\
\hline $\begin{array}{l}0.8 \text { million } \\
+ \text { rapeseed }\end{array}$ & 3 & 2.03 & 0.08 & 0.97 & 0.11 & 1.07 & 0.09 \\
\hline
\end{tabular}




\begin{tabular}{|c|c|c|c|c|c|c|c|}
\hline $\begin{array}{l}0.6 \text { million } \\
+ \text { rapeseed }\end{array}$ & 4 & 2.19 & 0.26 & 0.98 & 0.20 & 1.21 & 0.17 \\
\hline $\begin{array}{l}0.4 \text { million } \\
+ \text { rapeseed }\end{array}$ & 4 & 1.91 & 0.22 & 0.76 & 0.04 & 1.15 & 0.21 \\
\hline $\begin{array}{l}\text { Rapeseed } \\
1.25 \text { million }\end{array}$ & 5 & 1.58 & 0.30 & - & - & 1.58 & 0.30 \\
\hline $\mathrm{LSD}_{05}$ & & 0.18 & & 0.12 & & 0.11 & \\
\hline \multicolumn{8}{|c|}{ Lugovskaya 98 variety } \\
\hline $\begin{array}{l}1.3 \text { million } \\
\text { (contr.) }\end{array}$ & 1 & 1.67 & 0.39 & 1.67 & 0.25 & - & - \\
\hline $\begin{array}{l}1.3 \text { million } \\
+ \text { rapeseed }\end{array}$ & 2 & 2.88 & 0.13 & 2.21 & 0.31 & 0.67 & 0.09 \\
\hline $\begin{array}{l}0.8 \text { million } \\
+ \text { rapeseed }\end{array}$ & 3 & 3.10 & 0.29 & 2.23 & 0.27 & 0.87 & 0.14 \\
\hline $\begin{array}{l}0.6 \text { million } \\
+ \text { rapeseed }\end{array}$ & 4 & 2.83 & 0.18 & 1.99 & 0.26 & 0.84 & 0.17 \\
\hline $\begin{array}{l}0.4 \text { million } \\
+ \text { rapeseed }\end{array}$ & 4 & 2.89 & 0.20 & 1.83 & 0.37 & 1.07 & 0.18 \\
\hline $\begin{array}{l}\text { Rapeseed } \\
1.25 \text { million }\end{array}$ & 5 & 1.34 & 0.37 & - & - & 1.34 & 0.14 \\
\hline $\mathrm{LSD}_{05}$ & & 0.18 & & 0.21 & & 0.15 & \\
\hline
\end{tabular}

In mixed crops of the Lugovskaya 98 variety, when seeding $0.8-1.3$ million, the yield of vetch was $2.21-2.23 \mathrm{t} / \mathrm{ha}$, which is $33.5-35.6 \%$ higher than in mono-seeding, when seeding 0.4-0.6 million - $1.83-1.99 \mathrm{t} / \mathrm{ha}, 9.6-19.2 \%$ higher. The total yield of two-component mixtures ranged from 2.83 to $3.10 \mathrm{t} / \mathrm{ha}$, which is higher compared to mono-seeding by 1.16 $1.43 \mathrm{t} / \mathrm{ha}$ or $69.5-85.6 \%$.

The most complete picture of the effectiveness of mixtures and the causes of changes occurring within a mixed crop is given by such indicators as the intensity of land use - Land Equivalent Ratio (LER), the coefficient of competitiveness - Competitive Ratio (CR) and the coefficient of aggressiveness - Coefficient Agressivity (CA) [12].

The LER coefficient is used to evaluate the biological efficiency of mixed crops. It shows the ratio of the estimated land area required to produce the same amount of yield for each crop in a mono-crop that was formed per unit of mixed-crop area. To do this, the yield of crop A in mixed sowing with crop B (Yab) is divided by the yield of crop A in pure sowing (Yaa). Yab:Yaa ratio shows how much land it would take to produce a Yab crop if crop A was grown in a clean crop. This ratio is also calculated for culture B. The LER criterion can be calculated using the formula (1):

$$
L E R=L E R a+L E R b, \quad L E R a=\frac{Y a b}{Y a a}, L E R b=\frac{Y b a}{Y b b}
$$

The competitiveness coefficient CR is the LER ratio of two component crops, but taking into account the proportions in which the crops were sown (2).

$$
C R a b=\frac{L E R a}{L E R b} \bullet \frac{Z b a}{Z a b}, \quad C R b a=\frac{L E R b}{L E R a} \bullet \frac{Z a b}{Z b a}
$$

$\mathrm{CRab}$ - coefficient of competitiveness of crop A mixed with crop B; Crba - coefficient of competitiveness of crop B mixed with crop A; Zab and Z ba - ratio of crops A and B in the mixture, expressed in \% [12].

Evaluation of Land Equivalent Ratio (LER) shows that when using polymorphic vetchrapeseed crops, the productivity of 1 ha of arable land increases significantly: $-1.82-1.98$ times for the Lugovskaya 98 variety; $1.38-1.62$ times for the Luba variety. These results are achieved due to the absence of antagonism of vetch and rapeseed plants in the agrocenosis, and possibly due to the presence of positive plant allelopathy (table 2). 
Table 2. Evaluation of the effectiveness, competitiveness and aggressiveness of crops and changes occurring within mixed crops

\begin{tabular}{|l|c|c|c|c|c|c|c|}
\hline \multicolumn{1}{|c|}{ Variant } & $\begin{array}{c}\text { LERab, } \\
\text { vetch }\end{array}$ & $\begin{array}{c}\text { LERba, } \\
\text { rapeseed }\end{array}$ & LER & $\begin{array}{c}\text { CRab } \\
\text { vetch }\end{array}$ & $\begin{array}{c}\text { CRba } \\
\text { rapeseed }\end{array}$ & $\begin{array}{c}\text { CAab } \\
\text { vetch }\end{array}$ & $\begin{array}{c}\text { CAba } \\
\text { rapeseed }\end{array}$ \\
\hline \multicolumn{7}{|c|}{ Lyuba variety } \\
\hline $\begin{array}{l}1.3 \text { million + } \\
\text { rapeseed }\end{array}$ & 1.01 & 0.61 & 1.62 & 1.64 & 0.61 & 0.94 & -0.94 \\
\hline $\begin{array}{l}0.8 \text { million + } \\
\text { rapeseed }\end{array}$ & 0.84 & 0.68 & 1.51 & 2.01 & 1.32 & 1.03 & -1.03 \\
\hline $\begin{array}{l}0.6 \text { million }+ \\
\text { rapeseed }\end{array}$ & 0.84 & 0.77 & 1.61 & 2.39 & 1.97 & 1.51 & -1.51 \\
\hline $\begin{array}{l}0.4 \text { million }+ \\
\text { rapeseed }\end{array}$ & 0.66 & 0.73 & 1.38 & 2.92 & 3.61 & 1.77 & -1.77 \\
\hline to5 $\times \boldsymbol{S}_{\overline{\boldsymbol{x}}}$ & 0.14 & 0.09 & 0.29 & 0.11 & 0.06 & 0.11 & 0.06 \\
\hline \multicolumn{2}{|c|}{ Lugovskaya 98 variety } & & & \\
\hline $\begin{array}{l}1.3 \text { million }+ \\
\text { rapeseed }\end{array}$ & 1.32 & 0.50 & 1.82 & 2.65 & 0.38 & 1.75 & -1.75 \\
\hline $\begin{array}{l}0.8 \text { million }+ \\
\text { rapeseed }\end{array}$ & 1.34 & 0.65 & 1.98 & 3.34 & 0.79 & 2.36 & -2.36 \\
\hline $\begin{array}{l}0.6 \text { million }+ \\
\text { rapeseed }\end{array}$ & 1.19 & 0.63 & 1.82 & 4.12 & 1.14 & 2.80 & -2.80 \\
\hline $\begin{array}{l}0.4 \text { million }+ \\
\text { rapeseed }\end{array}$ & 1.10 & 0.80 & 1.89 & 4.46 & 2.37 & 3.51 & -3.51 \\
\hline to5 $\times \boldsymbol{S}_{\overline{\boldsymbol{x}}}$ & 0.13 & 0.09 & 0.10 & 0.07 & 0.06 & 0.07 & 0.06 \\
\hline
\end{tabular}

When sowing vetch with a rate of $0.6-1.3$ million germinating seeds per hectare, the main contribution to improving the efficiency of arable land use is made by spring vetch (LERab) due to its preferential competitiveness in the agrocenosis (CRab). When the seeding rate is lowered to 0.4 million / ha, the increase in yield and efficiency of arable land use is achieved due to the interaction of both crops (LERad+LERba) and an increase in competitiveness in the agrocenosis of each crop (CRab and CRba), which probably indicates an increase in positive allelopathy of plants with spaced seeding of vetch. These patterns are evident for all wiki varieties.

The aggressiveness coefficient $\mathrm{CA}$ is determined based on the change in the yields of both components in the mixture to their expected yield (3). The greater the numerical value of CA, the greater the difference in the competitive ability of the mixture components. Both components will have the same CA value, but the sign of the more aggressive component of the mixture will be positive.

$$
C A a b=\frac{Y a b}{Y a a \cdot Z a b}-\frac{Y b a}{Y b b \bullet Z b a}
$$

Analyzing the dynamics of changes in the aggressiveness of the crop in the agrocenosis with rapeseed by vetch varieties, an increase in the aggressiveness coefficient is noted with a decrease in the vetch seeding rate. In more space vetch crops in the agrocenosis with rapeseed plants, favorable conditions are formed for both crops, but it is vetch plants that dominate. Thus, with a seeding rate of $0.4 \mathrm{million} / \mathrm{ha}$, compared with seeding of 1.3 million/ha, the aggressiveness coefficient of the crop increases in the Lyuba variety - by 1.88 times (from 0.94 to 1.77 ) and in the Lugovskaya 98 variety - by 2.0 times (from 1.75 to 3.51 ). 
The sum of the coefficients of biological efficiency, competitiveness and aggressiveness $(\mathrm{LER}+\mathrm{CR}+\mathrm{CA})$ for each crop allows to give a comprehensive assessment of the actual and expected behavior of crops in the agrocenosis when the ratio of components changes.

Evaluation of vetch varieties with different vegetation periods and biological characteristics shows the actual dominance of vetch when growing for grain in vetchrapeseed crops (table 3 ).

Table 3. Distribution of the sum of coefficients of biological efficiency, competitiveness and aggressiveness depending on vetch seeding rate $(\mathrm{LER} a b+\mathrm{CRab}+\mathrm{CAab})$

\begin{tabular}{|c|c|c|c|c|}
\hline \multirow{2}{*}{ Variant } & Vetch & Rapeseed & Vetch & Rapeseed \\
\cline { 2 - 5 } & \multicolumn{3}{|c|}{ Lyuba } & \multicolumn{2}{c|}{ Lugovskaya 98 } \\
\hline 1.3 million + rapeseed & 3.59 & 0.28 & 5.72 & -0.87 \\
\hline 0.8 million + rapeseed & 3.88 & 0.97 & 7.04 & -0.92 \\
\hline 0.6 million + rapeseed & 4.74 & 1.23 & 8.11 & -1.03 \\
\hline 0.4 million + rapeseed & 5.35 & 1.40 & 9.07 & -0.34 \\
\hline
\end{tabular}

Regardless of the variety, the most unfavorable conditions for the development of rapeseed will develop in heavy seedings, and in space seedings there is a positive allelopathy of the development of rapeseed and vetch plants. Thus, it is possible to expect lodging of crops when sowing vetch with a rate of 1.3 million/ha and to expect a decrease in the yield of vetch grain due to an increase in the yield of rapeseed in its space seedings ( $0.4 \mathrm{million} / \mathrm{ha})$. Studies have shown that in vetch-rapeseed mixed crops, the main component of the crop will be vetch.

\section{Conclusions}

The cultivation of vetch-rapeseed agrocenoses can become an affordable and economically viable way to produce fodder grains and vetch seeds. The proposed technology in the conditions of the Sverdlovsk region allows to consistently get fodder grain vetch, while the productivity of 1 ha of arable land increases by 1.38-1.98 times.

The cultivation of grain-fodder varieties of vetch with a high protein content in grain exceeding peas can become an essential support in the production of fodder protein in the Sverdlovsk region and other regions.

\section{References}

1. A.P. Gaganov, Z.N. Zverkova, Chief zootechnician, 3, 33-40 (2018)

2. A.N. Kudryzvtsev, Legumes and cereals, 11(3), 45-7 (2014)

3. V.I. Zaparnyuk, Legumes and cereals, 1(17), 57-63 http://journal.vniizbk.ru/jurnals/17/j_vniizbk_2016_1-057-063

4. O.N. Telichko, Bulletin of Altai State Agrarian University, 2(136), 22-7 (2016)

5. E.A. Toshkina, K.A. Ambratsumova, A.A. Toshkina Economic substantiation of mixed agrophytocenoses of sowing vetch with different components in the conditions of the Novgorod region (Veliky Novgorod: Private scientific and educational institution of additional professional education Humanitarian National Research Institute "NATSRAZVITIE"; 2018)

6. K.A. Ambartsumova, E.A. Toshkina, Proceedings of the Kuban State Agrarian University, 72, 25-70 (2018) 
7. A.P. Drobyshev, V.P. Oleshko, V.I. Usenko, E.P. Shukis, D.A. Pugach, Bulletin of Altai State Agrarian University, 8(178), 5-14 (2019)

8. N.P. Lukashevich, I.M. Koval, T.M. Shloma, T.V. Kovaleva, A.S. Petrovich, Scientific notes of the educational institution Vitebsk Order Badge of Honor State Academy of Veterinary Medicine, 2(54), 102-6 (2018)

9. T. Génard, P. Etienne, P. Laîné, J.C. Yvin, S. Diquélou, Heliyon, 2(9), 1-15 (2016) http://dx.doi.org/10.1016/j.heliyon.2016.e00150

10. A. Couëdel, L. Alletto, É. Justes, Plant Soil, 426(1-2), 61-76 (2018)

11. A.V. Bezgodov, V.F. Akhmetkhanov, A.D. Yalunina, Legumes and cereals, 2(22), 73 9, 2017

12. N.A. Laman, V.P. Samsonov, V.N. Prokhorov, K.G. Shashko, I.N. Putyrsky, V.M. Kravchenko, Methodological guide for the study of mixed agrophytocenoses (Minsk: 'Navuka and Tekhnika', 1996) 